\title{
Optimaliasi Fungsi Pengorganisasian Dalam Meningkatkan Kualitas Pelayanan Ibadah Haji
}

\author{
Sona Sofyan Permana ${ }^{1 *}$, Arif Rahman $1^{1}$, Syamsudin RS $2^{2}$ \\ ${ }^{12}$ Jurusan Manajemen Dakwah, Fakultas Dakwah dan KomunikasiUIN Sunan Gunung Djati, \\ Bandung \\ 3 Jurusan Pengembangan Masyarakat Islam, Fakultas dan Komunikasi, UIN Sunan Gunung \\ Djati, Bandung \\ *Email: Sonasofyanfidkom@gmail.com
}

\begin{abstract}
ABSTRAK
Penelitian ini bertujuan untuk mengetahui bagaimana proses pengorganisasian yang dilakukan oleh kepala seksi Penyelenggaraan Haji dan Umrah Kementerian Agama Kabupaten Garut, terhadap pegawai dalam penyelenggaraan Haji dan bagaimana kebijakan yang dilakukan oleh kepala seksi dalam meningkatkan kualitas pelayanan. Metode penelitian ini menggunakan metode deskriptif Teknik pengumpulan data dalam penelitian ini yaitu melalui observasi, wawancara, dan studi dokumentasi. Adapun analisis data dilakukan melalui penafsiran logika yang dihubungkan dengan konteks Manajemen Dakwah. Hasil penelitian menunjukkan bahwa: Pertama, standar pelayanan yang ditetapkan di Seksi Penyelenggaraan Haji dan Umrah; Kedua, proses pembagian kerja yang dilakukan oleh Kepala Seksi Penyelenggaraan Haji dan Umrah dalam meningkatkan kualitas pelayanan; Ketiga, pendelegasian wewenang yang dilakukan oleh Kepala Seksi Penyelenggaraan Haji dan Umrah dalam meningkatkan kualitas pelayanan. Secara umum penelitian ini dapat disimpulkan bahwa pola pengorganisasian yang dilakukan oleh Kepala Seksi Penyelenggaraan Haji dan Umrah ini sudah tepat, dengan adanya proses evaluasi dan tindakan perbaikan sehingga program kerja yang telah ditetapkan dapat berjalan dengan efektif dan lancar.
\end{abstract}

\section{Kata Kunci : Pengorganisasian; Penyelenggaraan Haji dan Umrah; Pelayanan Ibadah haji.}

\begin{abstract}
This research aims to find out how the organizing process is carried out by the section head of the Hajj and Umrah organizers of the Ministry of Religion of Garut. Regency towards employees in the implementation of Hajj, and how policies are carried out in improving service quality. The method presented in this
\end{abstract}


study is the technique descriptive method in collecting this data by observing, interviewing and documenting studies. As for the data analysis done with the interpretation of logic which is related to the context of da'wah management, the results of the study show that: First, service standards set in the Hajj and Umrah Implementation Section; Second, the process of division of labor carried out by the Section Head of Hajj and Umrah Implementation in improving the quality of services; Third, delegation of authority is carried out by the Section Head for Hajj and Umrah Implementation in improving service quality. In general, this study can be concluded that the organizational pattern carried out by the Head of Hajj and Umrah Implementation Section is appropriate, with the evaluation process and corrective actions so that the work program that has been established can run effectively and smoothly.

Keywords: Organizing; Organizing Hajj and Umrab; Hajj services.

\section{PENDAHULUAN}

Sebagai negara dengan mayoritas muslim terbanyak di dunia, dengan populasi penduduk yang sangat banyak memungkinkan kalau Negara ini adalah pengirim Jemaah haji yang tiap tahunya selalu meningkat, dengan kuota Jemaah yang seperti itu pemerintah dalam posisinya adalah penanggung jawab sebagai lembaga yang menaungi sistem dan pengorganisasian dalam penyelenggaraan ibadah haji di Indonesia.

Dalam setiap tahunnya jumlah Jemaah haji di Indonesia sangat meningkat pesat dengan selalu terpenuhinya jumlah porsi yang telah di tetapkan oleh Organisasi Komprensi Islam (OKI). Peningkatan tersebut tentu saja menuntut para penyelenggara ibadah haji untuk mampu memberikan pembinaan, pelayanan dan perlindungan dengan menyediakan fasilitas keamanan dan kenyamanan yang di perlukan oleh warga Negara yang menunaikan ibadah haji.

Pelaksanaan ibadah haji di Indonesia secara nasional menjadi wewenang Kementerian Agama (Kemenag). Dalam kewenangan tersebut juga terkandung tanggung jawab yang besar karena dalam pelaksanaan ibadah haji diperlukan pelayanan yang baik. Pelayanan ibadah haji tidak hanya menyangkut kesejahteraan lahir dan batin jamaah haji, namun menyangkut nama baik dan martabat bangsa Indonesia di luar negeri, khususnya di Arab Saudi. Mengingat pelaksanaannya bersifat massal dan berlangsung dalam jangka waktu yang terbatas, maka penyelenggaraan ibadah haji memerlukan manajemen yang baik, agar penyelenggaraan ibadah haji tersebut dapat berjalan dengan tertib, aman, dan lancar.

Sejauh ini yang peneliti dapatkan pada saat melakukan wawancara awal dengan pihak Kemenag Kota Garut bahwa pengorganisasian mengenai 
pelaksanaan proses penyelenggaraan ibadah haji ini dinilai belum maksimal. Namun dalam prakteknya Undang-Undang Nomor 13 Tahun 2008 belum menjawab harapan masyarakat karena masih terdapat permasalahanpermasalahan yang terjadi dilapangan salah satunya terkait dengan kurang optimalnya sosialiasi mengenai system penyelenggaraan haji yang di lakukan oleh Kementrian Agama Kabupaten Garut jadi beberapa calon jamaah belum paham mengenai mekanisme pelaksanaan haji apalagi proses di lapangan nanti. Berangkat dari permasalahan ini maka dibutuhkan pengorganisasian yang baik dan benar pada saat akan dilaksanakannya penyelenggaraan ibadah haji. Maka dari itu perlunya pimpinan yang bisa mengelola lembaga yang dinaunginya agar tingkat kedisiplinan pegawai lebih maksimal dalam mememahi jobdescnya dan pimpinan juga perlu kiranya mengetahui lebih jauh bagaimana manajemen pelayanan ibadah haji, yang artinya sistem manajemen yang sejatinya dapat menjalankan fungsifungsi merencana, mengorganisasi, mengarahkan dan mengawasi kegiatan penyelenggaraan haji demi terlaksananya penyelenggaraan ibadah haji yang aman, lancar, dan berjalan dengan baik (Pasal 5 Undang-Undang No 17 Tahun 1999 tentang tentang Penyelenggaran Ibadah Haji). Penyelenggaraan ibadah haji akan berjalan dengan baik apabila didukung dengan pengorganisasian yang baik agar dapat mencapai tujuan yang diharapkan. Dalam aktifitas penyelenggaraan ibadah haji, pengorganisasian sangatlah dibutuhkan. Pengorganiasian mempunyai kedudukan penting dalam suatu lembaga. Tanpa pengorganisasian yang baik kegiatan-kegiatan suatu lembaga yang dilaksanakan tidak dapat dicapai tujuannya. Jadi, secara teoritis keberhasilan suatu lembaga terletak pada kemampuan pimpinan lembaga beserta staf pengurus lembaga lainnya yang secara operasional melakukan pengelolaan terhadap organisasi untuk mencapai suatu tujuan tertentu. (Depag, 2009)

Setiap lembaga pasti memerlukan pegawai sebagai tenaga yang menjalankan setiap aktivitas yang ada dalam lembaga tersebut. Seorang pegawai merupakan aset terpenting yang memiliki pengaruh sangat besar terhadap kesuksesan sebuah lembaga atau kesuksesan sebuah kegiatan. Tanpa mesin canggih, lembaga dapat terus beroperasi secara manual, akan tetapi tanpa pegawai, lembaga tidak akan dapat berjalan sama sekali. Maka dari itu pada saat penyelenggaraan ibadah haji lembaga membutuhkan pegawai yang dapat membantu mencapai tujuan dan membutuhkan pegawai yang dapat mengerti tentang proses penyelenggaraan ibadah haji serta dapat memahami setiap aspek yang dibutuhkan oleh jamaah haji agar jamaah haji tidak tersesat karena tidak memahami alur perjalanan ibadah haji pada saat praktik dilapangan.

Berdasarkan data diatas, kita dapat melihat bahwa dalam penyelanggaraan ibadah haji dibutuhkan persiapan yang matang dan dibantu dengan manajemen yang baik yang dilakukan oleh setiap unsur manajemen (men/manusia) baik itu 
pemimpin maupun pegawai agar tidak terjadi lagi permasalahan yang begitu kompleks pada saat eksekusi dilapangan. Maka dari itu, penulis tertarik untuk meneliti tentang "Optimalisasi Fungsi Pengorganisasian Dalam Meningkatan Kualitas Pelayanan Ibadah Haji (Studi Deskriptif pada Kementrian Agama Kabupaten Garut)".

Penelitian ini di lakukan di Kementrian Agama Kabupaten Garut pada bidang Haji yang beralamat di Jl. Terusan Pahlawan No.66 Sukagalih, Tarogong Kidul, Kabupaten Garut Jawa Barat 44151. Pengambilan lokasi tersebut mengingat besarnya kemungkinan penelitian dapat di laksanakan dengan melihat data data yang di butuhkan dalam penelitian ini tersedia, dan adanya korelasi dengan pihak kemenag dalam mengumpulkan data hingga tidak terlalu sulit. Dilihat dari pertimbangan kesesuaian dengan latar belakang akademik penyusun, penelitian ini tepat dilaksanakan mengingat ada kolerasi antara penyusum yang sedang studi tentang manajemen dakwah dengan pengambilan judul dan objek penelitian tersebut.

Adapun pertanyaan pada penelitian ini yaitu bagaimana proses pelayanan administrasi di Kementrian Agama Kabupaten Garut, bagaimana proses pembagian kerja di Kementrian Agama Kabupaten Garut, bagaimana Proses pendelegasian wewenang di Kementrian Agama Kabupaten Garut. Metode penelitian yang digunakan oleh peneliti yaitu metode penelitian deskriptif Metode deskriptif yaitu suatu rumusan masalah yang memandu penelitian untuk mengeksplorasi atau memotret situasi sosial yang akan diteliti secara menyeluruh, luas, dan mendalam. Metode ini bertujuan untuk melukiskan secara sistematis fakta atau karakteristik populasi tertentu atau bidang tertentu secara faktual dan cermat. Dalam proses pengumpulan datanya ia lebih menitikberatkan pada observasi lapangan dan suasana ilmiah, dengan mengamati gejala-gejala, mencatat, mengategorikan, dan sedapat mungkin menghindari pengaruh kehadirannya untuk menjaga keaslian gejala yang diamati. (Rakhmat, 2001: 34-35). Dengan menggunakan metode ini peneliti akan menganalisis hasil pengumpulan data melalui observasi dan wawancara dengan kepala seksi Penyelenggaraan Haji dan Umrah Kementerian Agama Kabupaten Garut.

\section{LANDASAN TEORITIS}

Penelitian ini menggunakan teori manajemen Andrew F. sikula yang menyatakan manajemen pada umumnya di kaitkan dengan aktivitas aktivitas perencanaan, pengorganisasian, pengendalian, penempatan, pengarahan, pemotivasian, komunikasi dan pengambilan keputusan yang di lakukan oleh setiap organisasi dengan tujuan untuk mengkoordinasikan berbagai sumber daya yang di miliki oleh perusahaan sehingga akan di hasilkan suatu produk atau jasa secara efisien. 
Dalam pelaksanaan penyelenggaraan ibadah haji khususnya di negara Indonesia, yang semakin tahun jumlah kuota jamaah semakin meningkat di perlukan persiapan yang sangat matang dari pihak kementrian agama sebagai penanggung jawab penyelenggaraan ibadah haji, dengan menggunakan system manajemen yang baik maka pelaksanaan ibadah haji akan terlaksana dengan teratur. Dengan melakukan pengorganisasian yang efektif dan mengoptimalkan segala bentuk pelayanan yang membangkitkan kepercayaan dari para jamaah.

Menurut Syahrul dalam dalam bukunya yang berjudul pelayanan publik mengatakan bahwa yang di maksud dengan optimalisasi adalah suatu proses,cara atau perbuatan untuk menjadikan sesuatu paling baik dan paling tinggi. Dalam hal ini upaya organisasi atau lembaga yang berusaha untuk meningkatkan kualitas organisasinya. Hal ini juga merupakan perilaku organisasi. Sopiah menjelaskan bahwa perilaku organisasi adalah perilaku manusia atau tindakan,sikap manusia yang di ukur dan di amati.

Dalam literatur dewasa ini, arti organisasi beraneka ragam, tergantung dari sudut mana ahli yang bersangkutan melihatnya. Walaupun demikian, perbedaan arti tersebut dapat kita golongkan ke dalam salah satu dari dua pendapat mengenai organisasi tersebut.

Pengorganisasian merupakan salah satu fungsi penting dalam proses manajemen, yaitu untuk mengatur seluruh sumber sumber yang di butuhkan sehingga pekerjaan dalam pelaksanaan dapat sesuai dengan tujuan yang di telah di tetapkan. Pengorganisasian menjadi kegiatan dasar dalam proses manajemen. Pengorganisasian di lakukan untuk mengatur seluruh sumber daya yang ada agar dapat berperan dan berfungsi dalam rangka tercapainya tujuan yang telah di tetapkan. Sumber daya yang ada meliputi enam macam yang dalam ilmu manajemen di sebut sebagai unsur unsur manajemen. Keenam unsur tersebut adalah man (manusia), money (uang), material (bahan), machine (mesin), method (metode), dan marketing (pemasaran) (Hasibuan 1996:44).

Pengorganisasian adalah salah satu fungsi manajemen dan merupakan suatu proses yang dinamis, sedangkan organisasi merupakan alat/wadah yang statis. Pengorganisasian dapat di artikan sebagai penentuan pekerjaan pekerjaan yang harus dilakukan, pengelompokan tugas tugas dan membagi bagikan pekerjaan kepada setiap karyawan, penetapan departemen departemen (subsistem subsistem) serta penentuan hubungan hubungan.

Sedangkan organisasi berasal dari kata "organism" yang berarti menciptakan struktur dengan bagian bagian yang di integrasikan sedemikian rupa, sehingga hubunganya satu sama lain terikat oleh hubungan terhadap keseluruhanya. Organisai di artikan menggambarkan pola pola, skema, bagan yang menunjukan garis garis perintah, kedudukan karyawan dan hubungan hubungan yang ada $\mathrm{d}$ dalamnya (Hasibuan ,1996:22). 
Pengorganisasian dapat di pandang sebagai proses penyesuaian struktur organisasi dengan tujuan, sumber daya dan lingkunganya. Sedangkan struktur oganisasi adalah sebagai susunan dan hubungan antar komponen bagian bagian dan posisi dalam suatu perusahaan. (Stoner, 1993:295)

Pengorganisasian (organizing) adalah proses penyusunan orang dan sumberdaya fisik untuk melaksanakan rencana dan mencapai tujuan organisasi, pengorganisasian merupakan tahap lanjut setelah perencanaan agar impelementasi perencanaan dapat berjalan dengan efektif dan efisien (Kusnandi, 1999:210). Pengorganisasin terjadi karena kebutuhan dan aturan yang harus di ikuti agar pekerjaan yang di lakukan itu sesuai dengan rencana. Pola pola yang sudah di siapkan itu akan memudahkan pelaksanaan organisasi dalam menjalankan tugasnya dan pembentukan kelompok kelompok kerja akan menghasilkan kerja yang efektif.

Definisi di atas menunjukan, bahwa pengorganisasian adalah merupakan langkah pertama ke arah pelaksanaan dari rencana yang telah tersusun sebelumnya ,maka dari itu pengorganisasian yang baik akan menentukan bagaimana pelaksanaan akan berjalan dengan baik atau tidak karena sebagai salah satu fungsi penting untuk bisa mengorganisir segala elemen yang ada di organisasi dan dapat tergerak sebagai suatu kesatuan yang kuat.

Mengorganisir adalah suatu proses pengelompokan kegiatan kegiatan untuk mencapai tujuan tujuan dan penugasan setiap kelompok kepada seorang manajer, yang mempunyai kekuasan, yang perlu untuk mengawasi anggota anggota kelompok. Dengan cara mengorganisir orang orang di persatukan dalam pelaksanaan tugas tugas yang saling berkaitan (Terry, 2010:82).

Pengorganisasian adalah pembagian kerja yang di rencanakan untuk di selesaikan oleh anggota kesatuan pekerjaan, penetapan hubungan antar pekerjaan yang efektif di antara mereka, dan pemberian lingkungan dan fasilitas pekerjaan yang wajar sehingga mereka bekerja secara efisien, masih menurut siswanto pengorganisasian juga dapat di definisikan sebagai suatu pekerjaan membagi tugas, mendelegasikan otoritas dan menetapkan aktivitas yang hendak di lakukan oleh manajer pada seluruh hierarki organisasi (Siswanto, 2005:75).

Secara historis pengorganisasian bertujuan untuk menyebarkan seluruh kegiatan manusia karena individu tergantung dari masyarakatnya. Selain itu mereka mendapatkan perlindungan terhadap kekuatan anti sosial yang mengancam setiap individu. Tulisan tulisan tersebut dalam sejarah nenek moyang mereka berisi petunjuk petunjuk tentang pengorganisasian antara lain dalam angkatan bersenjata.

Pemerintah dan kelompok kelompok agama, kegiatan kegiatan tersebut berlangsung terus menerus hingga masa kini. 
Tujuan organisasi mencakup beberapa fungsi di antaranya yaitu memberikan pengarahan dengan cara menggambarkan keadaan masa yang akan datang yang senantiasa berusaha di kejar dan di wujudkan oleh organisasi. Dengan demikian tujuan tersebut menciptakan pedoman bagi landasan kegiatan organisasi. Tujuan organisasi adalah keadaan yang di kehendaki pada masa yang akan datang yang senantiasa di kejar organisasi agar dapat di realisasikan. Organisasi itu bahkan dapat mewujudkan citra masadepan yang di cita citakan, pada dasarnya prinsip semua organisasi mempunyai satu bagian formal yang di akui secara ekplisit dan kadang kadang bersifat khas menurut hukum yang berfungsi untuk menentukan tujuan utama dan melakukan perubahan seperlunya. Didalam organisasi tidak jarang tujuan utama di tentukan secara formal melalui pengambilan suara terbanyak.

Dalam Buku Manajemen Dasar Pengertian dan Masalah tujuan organisasi adalah keadaan yang di kehendaki pada masa yang akan datang yang senantiasa di kejar oleh organisasi dapat di realisasikan. Namun secara keseluruhan bagaimanapun semuanya memandang bahwa tujuan organisasi tidak lain adalah mencari keuntungan. Dalam kaitan ini usaha untuk mencapai keuntungan meruapakan suatu pilihan karena di pandang sebagai cara yang dapat di mamfaatkan untuk memenuhi tujuan pribadi maupun organisasi atau juga pada prinsipnya perusahaan swasta seharusnya mencari keuntungan. Dalam kedua masalah tersebut tujuan mereka hendaknya jangan di kacaukan dengan tujuan organisasi. (Etzioni, 1985: 8-9)

Dari uraian unsur unsur organisasi di atas dapat di tarik kebutuhan dalam pemenuhan organisasi dengan memperhatikan unsur yang ada di dalamnya yang pertama manusia sebagai unsur pokok berjalanya sebuah organisasi, kemudian struktur organisasi untuk mengetahui orang orang di dalamnya, kerja sama satu sama lain yang ada dalam pemenuhan berjalanya organisasi dan yang paling terpenting adanya tujuan yang akan di capai

Pengorganisasian adalah fungsi manajemen dan merupakan suatu proses yang dinamis sedangkan organisasi merupakan alat atau wadah yang statis. Pengorganisasian dapat di artikan penentuan pekerjaan pekerjaan yang harus di lakukan, pengelompokan tugas tugas dan membagi bagikan pekerjaan setiap karyawan, penetapan departemen departemen (subsistem) serta penentuan hubungan hubungan.

Dan organisasi adalah struktur tata pembagian kerja dan struktur tata hubungan kerja antara sekelompok orang pemegang posisi yang bekerja sama secara tertentu untuk bersama sama mencapai suatu tujuan tertentu

Aspek aspek penting dari definisi di atas adalah: (a) Adanya tujuan tertentu yang ingin di capai (b) Adanya system kerja sama yang terstruktur dari sekelompok orang (c) Adanya system pembagian kerja dan hubungan kerja antara sesame 
karyawan. d) Adanya penetapan dan pengelompokan kerja yang terintregrasi (e) Adanya keterikatan formal dan tata tertib yang harus di taati (f) Adanya pendelegasian wewenang dan koordinasi tugas tugas g) Adanya unsur unsur dan alat alat organisasi (h) Adanya penempatan orang orang dan alat alat organisasi.

Pelayanan adalah suatu kegiatan atau urutan kegiatan yang terjadi dalam interaksi langsung antara seseorang dengan orang lain atau mesin secara fisik, dan menyediakan kepuasan pelanggan dan pelayanan merupakan suatu proses dari keseluruhan dari pembentukan citra perusahaan, baik melalui media berita, membentuk budaya perusahaan secara internal, maupun melakukan komunikasi tentang pandangan perusahaan kepada para pemimpin pemerintahan serta public lainya yang bekepentingan. (Loina, 2003:38)

Suatu pelayanan akan terbentuk karena adanya proses pemberian layanan tertentu dari pihak penyedia layanan kepada pihak yang di layani. (Brata, 2004:67)

Pelayanan ialah pemenuhan kebutuhan melalui aktivitas orang lain secara langsung. Pelayanan pun di artikan sebagai setiap kegiatan/mamfaat yang di tawarkan suatu pihak kepada pihak lain yang pada dasarnya tidak berwujud dan tidak mengakibatkan kepemilikan apapun.

Pelayanan adalah suatu kegiatan atau urutan kegiatan yang terjadi dalam interaksi langsung secara seseorang dan orang lain atau mesin secara fisik, dan menyediakan kepuasan Jemaah. Dalam Kamus Besar Bahasa Indonesia, pelayanan di jelaskan sebagai usaha melayani kebutuhan orang lain, dan melayani adalah membantu menyiapkan (mengurus) apa yang di perlukan seseorang. Kegiatan pelaksanaan pelayanan haji meliputi: (a)Administrasi adalah seluruh proses kegiatan yang di lakukan dan melibatkan semua orang secara bersama dalam organisasi untuk mencapai tujuan organisasi yang telah di tetapkan, mulai dari proses pendaftaran,pembayaran,surat keimigrasian, (b) Bimbingan Manasik haji dan umroh dapat di lakukan menjadi tiga bagian yaitu:(1) Prahaji, bimbingan yang di lakukan sebelum berangkat ke Tanah Suci agar calon Jemaah mengerti dan memahami bagaimana cara beribadah haji dan umroh ketika berada di Tanah Suci nanti.(2) Bimbingan yang di lakukan ketika berada di Tanah Suci. Pembimbing mendampingi dan memberi pengarahan kepada Jemaah agar pelaksanaan ibadah haji sesuai dengan tata cara ibadah haji. (3) Pasca haji. Bimbingan yang di lakukan setelah pelaksanaan ibadah haji, untuk mempertahankan kemabruran haji. (c) Transportasi memegang peran yang cukup menentukan dalam pelaksanaan ibadah haji. Pergerakan jamaah dari daerah asal menuju ke Arab Saudi sampai kembali ke daerah asal memerlukan sarana transportasi yang sesuai dengan jarak tempuh perjalanan dan volume angkut (orang dan barang). (d) Akomodasi adalah salah satu unsur penting yang harus di perhatikan oleh para penyelenggara ibadah haji. Penyelenggara harus memberikan akomodasi dengan baik dan memuaskan 
sehingga para Jemaah lebih khusyuk dalam menjalankan ibadah. Pelayanan akomodasi di maksud antara lain pelayanan jasa penginapan yang di lengkapi dengan pelayanan makan, minum serta jasa lainya. (e) Konsumsi Kelayakan dalam penyajian makanan yang memenuhi standar gizi dan higienis merupakan pelayanan yang menjadikan jamaah merasa nyaman dan puas. Bila di bandingkan dengan fasilitas yang mereka terima dan rasakan, biaya yang mereka keluarkan untuk bisa melaksanakan ibadah haji menjadi seimbang. (f) Kesehatan pelayanan kesehatan di lakukan sebelum berangkat ke Tanah Suci, seperti medical check-up, suntikan vaksin meningitis dan H1N1. Pelayanan kesehatan adalah pemeriksaan, perawatan, dan pemeliharaan kesehatan agar jamaah tetap dalam keadaan sehat, tidak menularkan atau tertular penyakit selama menjalankan ibadah haji, serta kembali ke tanah air. (Sukayat, 2016:23)

Pembagian kerja dalam sebuah organisasi merupakan salah satu hal terpenting, dimana pada bagian tersebut seseorang yang bekerja dalam sebuah organisasi akan di bagi sesuai keahlian, kemampuan atau skill yang di milikinya. Tujuannya adalah agar pekerjaan yang di emban oleh orang tersebut dapat di laksanakan dengan baik sesuai dengan rencana awal yang telah di tetapkan.

Pembagian kerja yang telah di tetapkan oleh organisasi haruslah sesuai dengan tujuan organisasi, selain itu dalam pembagian kerja tersebut haruslah memiliki standar pasti agar tidak terjadinya kesalahan dalam pembagian kerja. Dalam hal ini pimpinan harus dapat memberikan penjelasan yang konkrit terhadap pekerjaan yang akan di emban oleh bawahanya tersebut, dan juga ia harus dapat melihat latar belakang seseorang agar tujuan organisasi dapat tercapai dengan baik.

Ahli ekonomi pertama yang membahas dan memperhatikan pentingnya pembagian kerja agar dapat berproduksi secara effisien (product economics) adalah Adam Smith. Ia memperhatikan bagaimana berproduksi secara effisien pada waktu timbulnya system produksi yang sederhana di rumah rumah tangga. Perkembangan dari produksi rumah tangga menjadi system produksi pabrik terdapat dalam industri tekstil, yang di lakukan pada abad pertengahan 18. Usaha usaha yang di lakukan dalam system produksi dari industry tekstil itu terutama di tujukan untuk dapat memproduksikan tekstil dalam jumlah yang relative lebih besar dengan kualitas yang lebih baik. (Smith, 2008:44).

Yang di maksud dengan pengdelegasian wewenang adalah penyerahan sebagian dari wewenang atasan kepada bawahan setelah di adakan penyerehan tugas pekerjaan kepada yang bersangkutan. Untuk dapat menjalankan tugas dengan baik, maka kepada para petugas atau pejabat harus di limpahi wewenang. Sebagai konsekuensi itu harus di sertai pertanggungjawaban yang sepadan. Wewenang di limpahkan itu meliputi wewenang untuk menjalankan tugasnya, wewenang untuk memerintah bawahanya dan wewenang untuk menggunakan fasilitas/peralatan yang di butuhkan. Atasan harus percaya sepenuhnya bahwa 
bawahan yang di limpahi wewenang itu mampu melaksanakan tugasnya dengan baik. Meskipun atasan telah melimpahkan wewenang kepada bawahan untuk menjalankan tugas, namun tidak berarti bahwa atasan lalu terlepas dari tanggung jawab. (Manulang, 1981:33).

\section{HASIL DAN PEMBAHASAN}

Penelitian ini dilakukan di Kementerian Agama Kabupaten Garut, kelurahan Tarogong Kaler. Rute menuju Kementerian Agama Kabupaten Garut ini dapat ditempuh menggunakan kendaraan roda dua maupun roda empat, apabila dari arah simpang lima yaitu arahnya ke barat menuju daerah samarang kemudian ke arah STKIP Garut . Lokasi Kementerian Agama Kota Sukabumi ini cukup mudah ditemukan karena berada di area pusat pemerintahan daerah Kabupaten Garut.

Kementerian Agama Kabupaten Garut merupakan instansi vertikal kementerian agama, dimana Kementerian Agama Kabupaten Garut ini mendukung pelaksanaan tugas dan fungsi Kementerian Agama dalam meningkatkan pelayanan pemerintah terhadap masyarakat dalam memberikan pembinaan keagamaan. Dalam upaya memberikan pelayanan, para pegawai harus melaksanakan tugas pokok dan fungsi Kementerian Agama dalam wilayah Kota/Kabupaten berdasarkan kebijakan Kepala Kantor Wilayah Kementerian Agama dan ketentuan perundang-undangan yang berlaku. Para pekerja di Kementerian Agama Kabupaten Garut ini mayoritasnya adalah ASN atau Pegawai Negeri Sipil (PNS) maka dari itu setiap Pegawai Negeri Sipil harus memiliki pakta integritas agar para pegawai dapat bertanggung jawab terhadap tugasnya masingmasing dan dengan adanya pakta integritas ini dapat mengantisipasi tindakan korupsi, kolusi, dan nepotisme yang mungkin sewaktu-waktu dapat dilakukan oleh para pegawai, selain memiliki pakta integritas para pegawai disini juga harus mengacu pada kode etik pns.

Hasil dari penelitian yang dilakukan di Kementerian Agama Kabupaten Garut khususnya di seksi penyelenggaraan haji dan umrah, peneliti mendapatkan hasil bahwa pengawasan yang dilakukan oleh kepala seksi penyelenggaraan haji dan umrah ini sangat baik, sehingga dapat membawa dampak baik dalam proses peningkatan kualitas pelayananya, kepala seksi penyelenggaraan haji dan umrah ini selalu dekat dengan para pegawainya sehingga para pegawainya menjadi semangat dalam menjalankan tugas mereka, karena prioritas utama dari mereka itu adalah pemberian pelayanan prima kepada para jamaah serta mengimplementasikan kode etik dan menjalankan apa yang tertulis pada pakta integritas mereka sebagai seorang pegawai negeri sipil.

Pada dasarnya setiap lembaga atau organisasi selalu melaksanakan proses pengorganisasian karena pengorganisasian ini merupakan tahapan-tahapan di 
dalam melaksanakan kegiatan program kerja pada suatu lembaga. Proses pengorganisasian yang baik akan memastikan tujuan yang telah ditetapkan dari awal kepengurusan atau setelah pembentukan lembaga dapat tercapai. Kementerian Agama Kabupaten Garut khususnya Seksi Penyelenggaraan Haji dan Umrah memerlukan pengorganisasian yang dilakukan oleh kepala seksi dalam pencapaian tujuan, pengorganisasian dapat dianggap sebagai sebuah pengukuran dan perbaikan terhadap pelaksanaan kerja yang dilakukan oleh pegawai agar rencana-rencana yang telah dibuat untuk pencapaian tujuan dapat terselenggara. Saat melakukan pengorganisasian Kepala Seksi PHU bukan untuk mencari kesalahan-kesalahan pegawai tetapi berusaha untuk menghindari terjadinya kesalahan serta berusaja memperbaiki jika terdapat kesalahan. Jadi pengorganisasian yang dilakukan oleh Kepala Seksi PHU itu dilakukan sebelum pelaksanaan kegiatan, pada saat pelaksanaan kegiatan dan setelah pelaksanaan kegiatan.

Proses pelaksanaan pengorganisasian yang dilakukan oleh Kepala Seksi PHU ini mengacu pada tahapan-tahapan pengorganisasian, dimana tahapantahapan tersebut dilakukan agar proses pengorganisasian berjalan efektif dan efisien. Adapun tahapan pelaksanaan pengorganisasian yang dilakukan oleh Kepala Seksi Penyelenggaraan Haji dan Umrah dalam meningkatkan kualitas pelayanan yaitu: Proses Pelayanan Administrasi, pembagian kerja dan pendelegasian wewenang.

Temuan dalam penelitian ini yaitu, proses pelayanan administrasi, proses pembagian kerja dan proses pendelegasian wewenang.

\section{Proses Pelayanan Administrasi}

Dalam melaksanakan penyelenggara ibadah haji, Kementerian Agama Kota Garut sebagai suatu organisasi, yang mana diharuskan memiliki manajemen pengelolaan yang baik untuk penunjang tercapainya suatu tujuan organisasi sehingga keberhasilan akan tercapai. Oleh karena itu, Kementerian Agama Kabupaten Garut menerapkan SOP yang sesuai dengan peraturan Undang-Undang penyelenggara Ibadah Haji Nomer 13 Tahun 2008, Peraturan Menteri Agama (PMA) Republik Indonesia Nomer 15 Tahun 2012, dan Keputusan Menteri Agama (KMA). Hal ini di karenakan SOP merupakan suatu pedoman yang berisi prosedur-prosedur operasional yang ada dalam suatu organisasi yang digunakan untuk memastikan bahwa semua keputusan dan tindakan yang dilakukan oleh orang-orang di dalam organisasi berjalan secara efektif dan efesien SOP juga memiliki manfaat untuk menjamin adanya standarisasi dalam pelayanan dan tanggapan kepada pihak luar organisasi dan mampu memastikan bahwa semua kegiatan organisasi berjalan secara efektif dan efesien (Depag, 2009)

Oleh karena itu penerapan SOP dalam pendaftaran ibadah haji di 
Kementrian Agama Kabupaten Garut merupakan keputusan tepat. Karena dengan di terapkan SOP dalam pendaftaran ibadah haji memberikan kemudahan dalam penyelenggaraanya.

\section{Tabel 1}

\section{Standar Operasional Prosedur}

\section{Proses Pendaftaran Haji Kementerian Agama Kabupaten Garut}

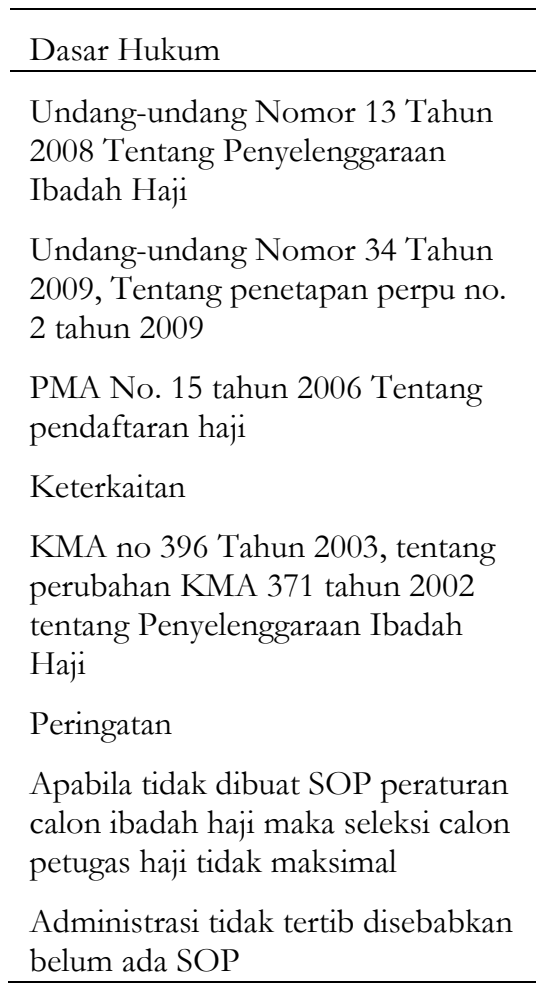

Sumber: SOP Seksi PHU Kemeterian Agama Kabupaten Garut

“... Pada proses pendaftaran administrasi itu di sesuaikan dengan standar operasional yang ada, sehingga para calon jamaah akan lebih mengetahui bagaimana pola dan tahapan pada pendaftaran administrasi haji, tetapi pada pelaksanaanya sering sekali para jemaah yang ingin mendaftar itu kelengkapan dokumennya itu kurang jadi sering terjadi hambatan pada proses pendaftaran" (Wawancara, 14 Mei 2018) 
Pelayanan adalah suatu kegiatan atau urutan kegiatan yang terjadi dalam interaksi langsung antara seseorang dengan orang lain atau mesin secara fisik, dan menyediakan kepuasan pelanggan dan pelayanan merupakan suatu proses dari keseluruhan dari pembentukan citra perusahaan, baik melalui media berita, membentuk budaya perusahaan secara internal, maupun melakukan komunikasi tentang pandangan perusahaan kepada para pemimpin pemerintahan serta public lainya yang bekepentingan. (Loina, 2003:38)

Pelayanan ialah sebuah usaha pemberian bantuan ataupun pertolongan pada orang lain, baik dengan berupa materi atau juga non materi agar orang tersebut bisa mengatasi masalahnya itu sendiri. (Suparlan, 2000:35)

Pelayanan adalah sebuah proses pemenuhan kebutuhan melalui aktifitas orang lain yang menyangkut segala masalah yang ditujukan orang lain untuk menyeleaikan masalah. (Loina, 2003:38)

\section{Proses Pembagian Kerja}

Fase kedua dalam proses pengorganisasian adalah pembagian kerja. Pimpinan Bidang PHU melakukan proses penempatan pegawai sesuai dengan kriteria dan keahlian yang di perlukan untuk menunjang kesuksesan pelaksanaan ibadah haji khususnya di daerah Kabupaten Garut dengan standar yang telah di tetapkan oleh Kementrian Agama Pusat dalam menciptakan kualitas pelayanan yang baik bagi para calon jamaah haji.

Dalam pelaksaanaanya sesuai dengan Undang-undang No. 13 tahun 2008 tentang penyelenggaraan ibadah haji merupakan pedoman dalam menyelenggarakan ibadah haji menyangkut rangkaian kegiatan pengelolaan pelaksanaan pembinaan, pelayanan, dan perlindungan kepada jemaah calon haji. Pembinaan, pelayanan, dan perlindungan adalah tiga unsur yang menjadi pilar penyangga keberhasilan pemerintah dalam menyelenggarakan ibadah haji. Lembaga pemerintah yang menjadi leading sector penyelenggara ibadah haji adalah Kementerian Agama. Kantor Kementerian Agama seksi penyelenggara ibadah haji dan umroh kabupen Garut sebagai leading sector dalam menyelenggarakan ibadah haji di kabupaten Garut, bertanggung jawab atas kesuksessan penyelenggaraan ibadah haji. Dalam rangka mencapai kesuksessan penyelenggaraan ibadah haji maka diperlukan manajemen pelayanan di kantor Kementerian Agama kabupaten Garut dengan memperhatikan proses pembagian kerja untuk meningkatkan pelayanan.

Tahap pertama, perencanaan pembagian kerja yang diterapkan di kantor Kementerian Agama kabupaten Garut dimulai dari perencanaan penyusunan program-program dalam memenuhi kebutuhan jemaah haji. Pelayanan ibadah haji di kantor Kementerian Agama kabupaten Garut. Apa yang menjadi tugas dan fungsi Kementerian Agama dalam UUD No. 13 tahun 2008 di susun dan 
dirancang dalam bidang-bidang pelayanan mulai dari pendaftaran sampai pemulangan jemaah calon haji. Perencanaan pelayanan yang dilakukan oleh Kementerian Agama kabupaten Garut antara lain: perencanaan pendaftaran, perencanaan pelunasan, perencanaan pembatalan, perencanaan pengelolaan dokumen perjalanan ibadah haji, perencanaan bimbingan manasik haji, perencanaan pembentukan karu dan karom, perencanaan pemberangkatan, dan perencanaan pemulangan. Perencanaan tersebut dilakukan dengan melihat peraturan perundang-undangan haji yang terbaru sesuai dengan intuksi Kementerian Agama republik Indonesia yang mengatur perihal penyelenggaraan ibadah haji tahun 2018. Landasan hukum yang menjadi pedoman dalam merencanakan program kerja di Kementerian Agama kabupaten Garut adalah Undang-Undang No. 13 tahun 2008 tentang penyelenggaraan ibadah haji, Peraturan Menteri Agama Nomor 14 Tahun 2012 tentang Penyelenggaraan Ibadah Haji Reguler, Peraturan Menteri Agama Nomor : 28 Tahun 2015 tentang Pembayaran Biaya Ibadah Haji Reguler Tahun 1436 H/ 2015 M, Peraturan Menteri Agama Nomor : 29 Tahun 2015 tentang Perubahan Atas Peraturan Menteri Agama. (Depag, 2009)

Tahap kedua, pengorganisasian pembagian kerja. Setelah bidang-bidang pelayanan yang telah terencanakan selanjutnya dilakukan pengorganisasian staf Kementerian Agama kabupaten Garut, pengorganisasian merupakan suatu kegiatan pengaturan sumberdaya manusia yang terdapat dalam suatu organisasi sesuai kemampuannya untuk menjalankan rencana yang telah ditetapkan dan menggapai tujuan organisasi pengorganisasian dimaksudkan memberikan pembagian tugas kerja, memberikan deskripsi pekerjaan yang menjadi tugas dan tanggung jawab masing-masing staf, dan menetapkan mekanisme kerja kesesuaian antar bidang perkerjaan dan keahlian. Pengorganisasian yang dilakukan di Kementerian Agama kabupaten Garut tahun 2018 adalah Drs. H. Karimudin., M.Pd. (sebagai ketua seksi penyelenggara haji dan umroh), H. Mamat Rahmat (sebagai pelaksna), Ahmad Rasyid Ridlah (sebagai pelaksana), Yedi Ahmad Hidayat (sebagai pelaksana), Dadang ( sebagai pelaksana)Tiktik Yani Herliani dan Vera Permata Rohani (sebagai pelaksana).

“...Proses pembagian kerja di bidang penyelenggaraan haji dan umroh Kementrian Agama Kabupaten Garut di sesuaikan depan Standar Operasional Prosedur (SOP) dan mengikuti pedoman yang sudah ada dari Keputusan Kementrian Agama Nomor 373 Tahun 2002 tentang penyelenggaran haji dan umroh yaitu melaksanakan pelayanan dan pembinaan di bidang penyelenggaraan haji..”. Wawanacara dengan Karimudin 16 Mei 2018.

Tahap ketiga, pelaksanaan pelayanan. Setelah dilakukan perencanaan dan 
pengorganisasian maka selanjunya pelaksanaan pelayanan. Pelayanan yang diberikan oleh kantor Kementerian Agama kabupaten Garut pada tahun 2018 antara lain: pelayanan pendaftaran / pelunasan, pelayanan pembatalan, pelayanan biaya penyelenggaraan ibadah haji, pelayanan dokumen-dokumen ibadah haji, pelayanan mutasi jemaah, pelayanan bimbingan manasik haji, pelayanan pembentukkan karu dan karom, pelayanan pemberangkatan, dan pelayanan pemulangan.

Pengorganisasian merupakan suatu kegiatan pengaturan sumberdaya manusia yang terdapat dalam suatu organisasi sesuai kemampuannya untuk menjalankan rencana yang telah ditetapkan dan menggapai tujuan organisasi. (Kusnawan, 2015)

Pembagian kerja yaitu informasi tertulis yang menguraikan tugas dan tanggung jawab, kondisi pekerjaan, hubungan pekerjaan, dan aspek-aspek pekerjaan pada suatu jabatan tertentu dalam organisasi. (Hasibuan, 2007: 33)

Pembagian tugas adalah hasil analisis pekerjaan sebagai rangkaian kegiatan atau proses menghimpun dan mengolah informasi mengenai pekerjaan. Pembagian kerja adalah rekaman tertulis mengenai tanggung jawab dari pekerjaan tertentu. Dokumen ini menunjukkan kualifikasi yang dibutuhkan untuk jabatan tersebut dan menguraikan bagaimana pekerjaan tersebut berhubungan dengan bagian lain dalam perusahaan (Rivai, 2004: 125)

\section{Proses Pendelegasian Wewenang}

Proses pengorganisasian yang ketiga adalah pendelegasian wewenang yang di lakukan oleh Seksi PHU Kementrian Agama Kabupaten Garut dalam meningkatkan kualitas pelayanan, proses pendelegasian wewenang di lakukan untuk mengefektifkan pekerjaan, atau aturan yang sudah di tetapkan oleh Kementrian Pusat dalam mengregenerasi pegawai untuk menjaga kestabilan penyelenggaraan haji di Indonesia.

Keputusan Menteri Agama Republik Indonesia Nomor 494 Tahun 2003 tentang pemberian kuasa dan pendelegasian wewenang pengangkatan, pemindahan dan pemberhentian pegawai negeri sipil dalam lingkungan Departemen Agama.

Kementrian Agama sebagai salah satu organisasi pemerintah di tuntut untuk meningkatkan fleksibiltas dalam geraknya antara lain dengan senantiasa meninjau kembali pendelegasian wewenang antar satuan organisasi/satuan kerja baik di tingkat pusat maupun tingkat daerah sesuai tuntutan kebutuhan pelayanan masyarakat yang semakin meningkat.

Makin banyak tugas tugas yang di delegasikan ke bawah, pimpinan lebih banyak berfikir/berkosentrasi kepada hal hal yang bersifat kebijaksanaan dan strategis,dan pekerjaan pelaksanaan makin mengalir ke bawah dengan imbangan 
pengawasan oleh pimpinan harus lebih di tingkatkan. Berdasarkan pertimbangan tersebut maka Kementrian Agama menyusun pedoman pendelegasian wewenang di lingkungan Kementrian Agama pusat sampai ke Kementrian Agama daerah dan bagi semua yang terkait.

Petunjuk pelaksanaan pendelegasian wewenang ini di tujukan kepada semua pihak yang terkait dalam pelaksanaan pendelegasian wewenang di lingkungan Kementrian Agama. Juklak pendelegasian wewenang ini mencakup pemberian tugas, pemberian wewenang untuk menjalankan tugas itu dan pemberian tanggung jawab atas pelaksanaan tugas tersebut. Prinsip dalam Pendelegasian wewenag Kementrian Agama Kabupaten Garut yaitu: (1) Prinsip sakalar, artinya bahwa dalam organisasi harus ada suatu garis wewenang yang jelas, yang berjenjang mulai dari tingkat yang paling tinggi sampai yang paling rendah. Garis wewenang yang jelas itu akan memudahkan setiap anggota organisasi untuk memahami (2) Siapa pejabat yang dapat mendelegasikan wewenag kepada pejabat lain (3) Kepada siapa pejabat dapat mendelegasikan wewenang 4) Kepada siapa pejabat penerima delegasi bertanggung jawab.5) Prinsip kesatuan komando, artinya setiap orang dalam satu organisasi bertanggung jawab kepada satu atasan.(6) Menghindarkan adanya tumpeng tindih, artinya bahwa tanggung jawab atas tugas yang sama/sejenis di serahkan kepada lebih dari satu orang.(7) Menghindarkan adanya pendelegasian wewenang melebihi dua tingkat ke bawah (8) Pelaksanaan tanggung jawab tidak terpecah pecah, artinya tanggung jawab atas tugas yang sama di serahkan kepada lebih dari satu unit organisasi.(9) Prinsip kecermatan, artinya pendelegasian wewenang di berikan dengan memperhatikan senioritas dari pejabat fungsional yang menerima delegasi.

Pelaksanaan Pendelegasian Wewenang di Kementrian Agama Kabupaten Garut di sesuaikan dengan pedoman pendelegasian wewenang yang ada. Dalam rangka persiapan di tempuh langkah langkah: (1) Melakukan inventarisasi dan analisis secara lengkap tugas tugas yang menjadi wewenang pemberi delegasi sesuai dengan ketentuan peraturan perundangan undangan yang berlaku.(2) Mendiskusikan dengan bawahan kewenangan dan tugas tugas apa yang mungkin untuk di delegasikan di sertai dengan mamfaat dan mudaratnya. (3) Menentukan bawahan yang akan diberi delegasi dengan mempertimbangkan kemampuan, keterampilan, kondisi fisik dan mentalnya. Dalam tahap pelaksanaan ada tugas subtantif dan fasilitatif yang harus dilakukan di antara lain: (a) Pendelegasian wewenang yang bersifat statuter di lakukan dengan Surat Keputusan. (b) Pendelegasian wewenang yang bersifat non statuter di lakukan dengan Surat Keputusan misalnya pendelegasian wewenang penandatangan surat surat dinas yang penting .(c) Pendelegasian wewenang yang berupa tugas harian dapat di lakukan secara tertulis maupun lisan baik dalam surat surat tugas, nota dinas 
maupun disposisi.

“... Pada pelaksaanaan pendelegasian wewenang itu selalu diterapkan untuk meningkatkan kualitas kerja dan hubungan antar pegawai, jika pendelegasian wewenang untuk pergantian dan pelantikan seorang pegawai/pejabat itu di sesuaikan dengan aturan dari Kementrian Agama sehingga pada tataran proses pelaksanaanya pun itu sesuai dengan aturan yang berlaku". Wawancara dengan Dr. H.Karimudin, M.Pd.

Penunjukan Kepala Pengganti Kementrian Agama Kabupaten Garut dalam hal seorang pejabat tidak dapat melaksanakan tugasnya baik untuk sementara maupun karena tidak ada pengganti yang tetap, maka pejabat yang berwenang menetapkan pejabat pengganti sesuai peraturan yang berlaku: 1) Pelaksana Harian (plh). 2)Penunjukan Plh di lakukan apabila terdapat pejabat yang akan meninggalkan tugas kurang dari satu bulan. Surat penunjukan sebagai pelaksana harian (plh) di tandatangani oleh atasan langsung satuan organisasi yang bersangkutan sepanjang tidak menyangkut tugas pengambilan keputusan yang bersifat kebijaksanaan dan yang berhubungan dengan Kantor Pembendaharaan dan Kas Negara (KPKN). 3) Pengganti Sementara (Pgs) Penunjukan pengganti sementara (pgs) di lakukan apabila terdapat kekosongan pejabat atau seorang pejabat akan meninggalkan tugas dan berakibat menganggu kelancaran tugas sehari hari baik yang yang menyangkut materil maupun finansial yang berhubungan dengan Kantor Pembendaharaan dan Kas Negara (KPKN). Surat Keputusan penunjukan pengganti sementara (pgs) di laksanakan oleh pejabat yang berwenang sesuai dengan Keputusan Menteri Agama Nomor 298 Tahun 1993 tanggal 22 November 1993. 4) Pejabat yang melaksanakan tugas (pymt) Penunjukan pymt di lakukan apabila seorang pejabat akan meninggalkan tugas lebih dari satu bulan. Surat penunjukan sebagai pejabat yang melaksanakan (pymt) di tandatangani oleh pimpinan satuan organisasi yang bersangkutan sepanjang tidak menyangkut tugas pengambilan keputusan yang bersifat kebijaksanaan dan yang berhubungan dengan Kantor Pembendaharaan dan Kas Negara (KPKN).

Wewenang adalah hak yang cukup untuk memunginkan seseorang dapat menyelasaikan suatu tugas kewajiban tertentu. Wewenang adalah sejumlah kekuasaan dan hak yang di delegasikan pada suatu jabatan (Davis, 2008:65)

Wewenang adalah kekuasaan yang sah, yang dimiliki oleh seseorang yang memiliki peran, baik dalam perusahaan atau organisasi. Hak ini berfungsi untuk memerintah dan bertindak.(Donnel,2011:64)

\section{PENUTUP}

Berdasarkan temuan dari penelitian yang telah dilaksanakan dan dibahas pada bab-bab sebelumnya, penulis dapat mengambil kesimpulan dari masalah yang 
penulis bahas yaitu tentang optimalisasi fumgsi pengorganisasian dalam meningkatkan kualitas pelayanan ibadah haji di Kementrian Agama Kabupaten Garut, berdasarkan data yang penulis peroleh maka dapat di ambil kesimpulan sebagai berikut:

Pertama, Pelayanan administrasi bagi calon jamaah sudah cukup baik sesuai dengan standar operansional prosedur yang berlaku (SOP). Pelayanan yang di lakukan oleh para pegawai seksi penyelenggaraan haji dan umroh itu bisa di katakana optimal dalam memenuhi kebutuhan administrasi calon jemaah haji. Pengarahan yang jelas dari setiap pegawai dalam memberikan informasi kepada calon jemaah di laksanakan dengan cukup baik pula, tapi hambatan yang sering muncul kadang kadang calon jamaah haji kurang mengerti tentang persiapan beberapa administrasi yang mungkin banyak dan beberapa dokumen selalu tidak lengkap. Maka dari itu seksi penyelenggaraan haji dan umroh Kabupaten Garut memberikan sosialisasi mengenai persiapan administrasi kepada calon jamaah sehingga calon jamaah lebih mengerti bagaimana pola administrasi yang baik dan benar.

Kedua, Pembagian kerja yang di lakukan cukup objektif dalam meningkatkan kualitas pelayanan penyelenggaraan ibadah haji, kebijakan local yang di lakukan pimpinan kasi haji untuk memenuhi kebutuhan jemaah dalam proses pendafatran dan tataran pelaksanaannya teratur Dilihat dari bentuk pembagian kerja yang di berikan kepada pegawai di kasi haji, kantor Kementerian Agama Garut memberikan bentuk pelayanan berupa pelayanan lisan, tulisan, dan perbuatan. Bentuk pelayanan lisan yang diberikan oleh kantor Kementerian Agama kabupaten Garut terwujud dalam memberikan penjelasan atau keterangan kepada jemaah calon haji terkait persyaratan dan prosedur pengurusan pendaftaran, pembatalan, ataupun mutasi dan peraturan regulasi yang sudah di tetapkan.

Ketiga, Pendelegasian wewenang yang di lakukan seksi penyelenggaraan haji dan umroh Kabupaten Garut di sesuaikan dengan kebutuhan pekerjaan dan regulasi yang telah di tetapkan pemerintah pusat dalam pelaksaanan dan penyelenggaraan ibadah haji. Penyesuaian dan pengangkatan seorang pegawai dalam memenuhi kebutuhan pekerjaan di lakukan jika memang pemimpin dalam porsinya tidak bisa atau ada hal yang penting yang harus di dahulukan. Dalam proses pelayanan pimpinan kasipun sering memberikan wewenang kepada para pegawainya untuk menggantikan proses pertemuan ataupun hal lainya yang berkaitan dengan proses pelaksanaan kegiatan penyelenggaraan ibadah haji agar tidak menjadi hambatan dalam pelaksanaan dan pelayanan dalam proses penyelenggaraan ibadah haji.

Berdasarkan hasil dari pemaparan kesimpulan di atas, maka penulis akan memberikan sedikit saran terkait pengorganisasian yang dilakukan oleh kepala seksi Penyelenggaraan Haji dan Umrah dalam upaya meningkatkan kualitas 
pelayanan, yaitu: (1) Pengorganisasian merupakan suatu cara agar pemimpin dapat mengetahui dan dapat menjadi tolak ukur pelayanan dan kinerja pegawai setiap harinya, maka dari itu diharapkan kepala seksi Penyelenggaraan Haji dan Umrah dapat lebih meningkatkan evektifitas pengorganisasian terhadap pegawainya agar tidak terjadi penyimpangan-penyimpangan yang berarti pada saat proses pengerjaan program kerja serta diharapkan dengan adanya pengorganisasian ini pegawai menjadi lebih dekat dengan atasannya dan pegawai bukan merasa terintimidasi karena merasa pekerjaannya diawasi. (2) Tujuan dari lembaga itu harus dapat di capai bersama, maka dari itu pemimpin harus bisa memberikan motivasi kepada pegawainya agar pegawai merasa nyaman dan merasa semangat agar tujuan yang telah ditentukan bersama dapat terlaksana dengan lancar dan sesuai dengan yang diharapkan.

\section{DAFTAR PUSTAKA}

. (1981). Manajemen Personalia. Jakarta Timur: Yudistira.

Davis K, Newstrom JW. (2008). Perilaku dalam Organisasi. Jilid 1. Terjemahan. Jakarta: Penerbit Erlangga.

Donnel, G J.L., J.M. Ivancevich, (2011). Organization: Structure, Process, Behavior. Dallas: Business Publication, Inc

Etzioni, A. (1985). Organisasi-Organisasi Modern. Alih bahasa oleh Suryatim. Jakarta: Diterbitkan atas kerja sama Universitas Indonesia dan Pustaka Bradjaguna. Hasibuan, M. S. (1996). Manajemen Sumber Daya Manusia. Jakarta: Bumi Aksara. Hasibuan, M. S. (2007). Manajemen Dasar, Pengertian, dan Masalah. Jakarta: Bumi Aksara.

Kusnawan, A. (2015). Konsep Manajemen Pelatihan Dakwah. Dalam Ilmu Dakwah: Academic Journal For Homiletic Studies, 4(12), 335-370. Kusnandi, (1999), Akuntansi Pemerintahan (Publik), Malang: Universitas Brawijaya

Loina L.K. (2003). Indikator dan Alat Ukur Prinsip Akuntabiitas, Transparansi dan Partisipasi. Jakarta.

Manulang, M. (2008). Dasar-Dasar Manajemen. Yogyakarta: Gadjah Mada University Press. - (1981). Manajemen Personalia. Jakarta Timur: Yudistira.

Rakhmat, J. (2001) Psikologi Komunikasi, Edisi Revisi, Bandung: PT.Remaja Rosda Karya

Rivai, V. (2004) Manajemen Sumber Daya Manusia Untuk Perusabaan. Jakarta: Pt. Raja Grafindo Persada.

Siswanto, B. (2005). Manajemen Tenaga Kerja Indonesia Pendekatan Administrarif dan Operasional. Jakarta: Bumi Aksara.

Smith, S.L.J. (2010) Practical Tourism Research, Oxford: CABI

Stoner A.F. J, dkk. (1996). Manajemen, Edisi Bahasa Indonesia. Jakarta : PT. 
S.S.Permana, A.Rahman, S.RS.

Prenhallindo.

Sukayat, T. (2016). Manajemen Haji, Umrah dan Wisata Agama. Bandung: Simbiosa Rekatama Media.

Suparlan, P. (2000). Kemiskinan Perkotaan dan Alternatif Penanganannya. Ditujukkan dalam Seminar Forum Perkotaan. Jakarta: Departemen Permukiman dan Prasarana Wilayah.

Terry, G \& Leslie W. R. (2010). Dasar-DasarManajemen. Cetakan kesebelas. Jakarta: PT Bumi Aksara. 